\title{
Possibilities of Inclusive Education for Students With Special Educational Needs
}

\author{
Jana Kožárová ${ }^{1}$ \\ ${ }^{1}$ Department of Special Education, Faculty of Education, University of Prešov in Prešov, Slovak Republic \\ Correspondence: Jana Kožárová, Faculty of Education, University of Prešov in Prešov. 17. Novembra 15, 08001 \\ Prešov, Slovak Republic.
}

Received: March 1, 2018

Accepted: April 6, 2018

Online Published: April 11, 2018

doi:10.20849/aes.v3i2.361

URL: https://doi.org/10.20849/aes.v3i2.361

\begin{abstract}
There are approximately 800 million young children worldwide affected by biological, environmental and psychosocial conditions that can limit their cognitive development. In Europe, recent estimates place the number of children with special educational needs (SEN) at 15 million. Conservative estimates state that dyslexia, a learning disability that impedes a person's ability to read, affects approximately 6 percent of Europe's population, whilst the prevalence of autistic spectrum disorders is also estimated to be higher than previously thought. Children with SEN frequently leave school with few qualifications and are much more likely to become unemployed or economically inactive. Children with SEN are children first and have much in common with other children of the same age. There are many aspects to a child's development that make up the whole child, including-personality, the ability to communicate (verbal and non-verbal), resilience and strength, the ability to appreciate and enjoy life and the desire to learn. Each child has individual strengths, personality and experiences so particular disabilities will impact differently on individual children. A child's special educational need should not define the whole child. Presented paper briefly introduces different categories of special educational needs and subsequently describies inclusive education as a concept potentially successful for their academic and vocational performance.
\end{abstract}

Keywords: special educational needs, special needs education, inclusion, inclusive education

\section{Introduction}

It has been already 50 years when Jacobus tenBroek (1966), professor of law at the University of California at Berkley, defended the legal right of people with disabilities "to be abroad in the land". In the intervening years, disability has come to the foreground of the landscape of bioethics, law, but particularly of the education as such. On nearly any classificatory measure, over $15 \%$ of the advanced industrialized countries population are currently identified as disabled. As population continue to age, these proportions will grow.

Throughout the world children who have disabilities and many others who experience difficulties in learning have traditionally been marginalized within or excluded from schools. All children, including children with special educational needs, have a right to an education which is appropriate to their needs. The aims of education for pupils with special educational needs are the same as apply to all children. Education should be about enabling all children, in line with their abilities, to live full and independent lives so that they can contribute to their communities, cooperate with other people and continue to learn throughout their lives. Education is about supporting children to develop in all aspects of their lives - spiritual, moral, cognitive, emotional, imaginative, aesthetic, social and physical.

Various claims are made about the success or failure of inclusion projects, for example Fauclat (1977) statement that: “... realized through technologies that make visible particular objects of scrutiny ... inclusion functions as a panoptic mechanism through techniques which allow the assignment to each individual his 'true' name, his 'true' place, his 'true' body, his 'true' disease..."

Such accounts tend to be mostly descriptive and usually take for granted that the inclusive project is a transcendental "good", a position which has been variously contested.

Talking about inclusive education implies talking about differences: how to deal with differences in schools, in classrooms, and in the curriculum in general. If schools, classrooms, and the curriculum in general fail to take differences between learners into account, inclusion will remain confident to a debate among policy-makers, 
experts and those not actually involved in practical education. Teachers have to cope with a variety of children in the classroom and need to know how to do so.

We have to be aware of how we approach pupils; differences among them normally follow a bell-shaped distribution. Unfortunately, very often the teachers assume that pupils have the same type of skills or starting point. Research shows, for example, that degrees of cognitive development can differ by up to almost 2 years among children at the age of six, which is when they begin school in some countries. So why do we expect all six-year-old children to have the same level when it comes to learning to read or understanding language?

When we are talking about inclusive education we need to define and clear out several facts. And also, clarify the current situation is Slovakia.

Inclusive education and the common schooling of all children with special educational needs in regular schools are part of European Union agenda for educational justice. Furthermore, UNESCO's Salamanca Declaration of 1994 is still an important point of reference for special needs education in Europe. All European states have ratified the Declaration and therefore agree that its core principles shall serve as a foundation for educational policy in general and not just on special needs education: Equity regarding the access to education as well as quality education for all respecting individual differences and putting strengths rather than weaknesses into focus. In many of the Southern European or Scandinavian countries, among them Italy, Norway and Sweden, about 95 percent of students with special needs attend regular schools. In Great Britain, the rate lies around 60 percent (UNESCO, 2016).

In the Slovak republic inclusive education of students with special educational needs has been on the increase since 1990, facing many challenges. The number of students with special educational needs receiving inclusive education at kindergartens, elementary and high schools in the Slovak republic are varying from year to year, but generally we could say that the number of students with special educational needs in mainstream settings has been growing (Hlebová et al., 2015).

Higher-incidence disabilities areas in inclusive settings include learning disabilities, intellectual and developmental disabilities, speech and language impairment and emotional disturbances (Mastropieri, Scruggs, 2007). The most frequent special educational needs in children and students educated in inclusive settings at various types of schools in Slovakia include learning disabilities, intellectual disabilities, communication disorders, and behavioral disorders. However, the number of children educated in inclusive settings keeps growing also owing to more severe disabilities, such as the autism spectrum disorders or multiple disorders. The group of children and students integrated in kindergarten, elementary and high school classes because of socially disadvantaged background which represents a substantial portion of students (see Table 1) has been monitored as a separate group by the Ministry of Education, Science, Research and Sports in the Slovak Republic since the school year 2010/2011.

Table 1. Summary of integrated children and students with special educational needs in kindergarten, elementary schools and high schools in Slovakia

\begin{tabular}{llll}
\hline Categories of special educational needs & $\mathbf{2 0 0 9 / 2 0 1 0}$ & $\mathbf{2 0 1 2 / 2 0 1 3}$ & $\mathbf{2 0 1 5 / 2 0 1 6}$ \\
\hline Learning disabilities & 13049 & $16981(\uparrow)$ & $18153(\uparrow)$ \\
Intellectual and developmental disabilities & 3778 & $3653(\downarrow)$ & $3830(\uparrow)$ \\
Physical impairment & 1454 & $1116(\downarrow)$ & $821(\downarrow)$ \\
Emotional and behavioral disorders & 1292 & $1031(\downarrow)$ & $832(\downarrow)$ \\
Speech and language impairments & 831 & $1112(\uparrow)$ & $1571(\uparrow)$ \\
Giftedness & 580 & $845(\uparrow)$ & $808(\downarrow)$ \\
Hearing impairments & 496 & $509(\uparrow)$ & $540(\uparrow)$ \\
Visual impairments & 385 & $405(\uparrow)$ & $405(\leftrightarrow)$ \\
Autism spectrum disorders & 190 & $327(\uparrow)$ & $566(\uparrow)$ \\
Other & $-* *$ & 2477 & $4968(\uparrow)$ \\
Socially disadvantaged background & - & 54257 & $15055(\downarrow)$ \\
Total & $\mathbf{2 2 0 5 5}$ & $\mathbf{8 2 7 1 3}$ & $\mathbf{4 7 5 4 9}$ \\
\hline
\end{tabular}

*Includes students with multiple disabilities, students with health problems, pupils with ADHD and ADD.

${ }^{* *}$ This data has been specified in more detail only recently and includes the above mentioned groups of children and students.

(Source: own processing based on the data of the Institute of Information and Prognosis in Education in the Slovak Republic). 
The growing number of students with special educational needs in Slovakia reflects the concurrent compliance with the national and international documents the Slovak Republic decided to abide by in the area of inclusive education. Promotion of inclusive principles, compliance with human rights in school, inclusion of students with special educational needs in Slovakia, and prohibition of all forms of discrimination, and particularly segregation, is based on the Act 245/20008 Coll. on education (School Act). But preparedness for, and implementation of, inclusive education of students with special educational needs continues to stumble over many obstacles. This may be also influenced by the long-lasting tradition of special education in segregated settings in Slovakia (Hrebeňárová et al, 2016). While several European countries, such as Norway (Groven, 2015), Finland, Sweden, Italy (Lechta, 2010) started to use integration, and later on, inclusive efforts as early as in the 1970s, other countries, including Slovakia, tend to continue in the tradition of special education of students with special educational needs in special schools.

In the paper we define and introduce 10 traditional categories of special education: intellectual and developmental disabilities, learning disabilities, attention deficit hyperactivity disorder, emotional/behavioural disorders, deaf and hard-of-hearing, blindness and low vision, autism spectrum disorders, multiple and severe disabilities, and special gifts and talents.

Although the popular trend is toward a non-categorical approach to special education, approaching special education from a categorical perspective helps the reader to understand the historical and foundational concepts that underpin each category. Clearly, the notion of non-categorical special education has garnered support; however, it is noteworthy that this support lies mainly in the areas if teacher certification and teacher preparation. This focus does not detract from the necessity to understand the unique characteristics and need of individuals with each disability. It is crucial to the ultimate success of exceptional learners that educators understand what practices are appropriate for whom, and under what conditions. A categorical approach to research may be the most effective method for determining best practices.

\section{Categories of Special Educational Needs}

\subsection{Intellectual and Developmental Disabilities}

The concept of intellectual disabilities represents a contemporary change from mental retardation, initially coined as an option to feeblemindedness (Polloway, 2006). The intellectual disabilities term has become the preferred referent for individuals across the lifespan. At the same time, because mental retardation is wellentrenched within our bureaucracy (such as in federal reports), we continue to use the term in this chapter as applicable.

Intellectual and developmental disabilities have provided a foundation for the broader filed of special education. A significant amount of the initial work in special education was concerned with individuals labelled mildly intellectually disabled. Subsequently, many of the leaders who shaped the field began their professional careers and/or made their major contributions in this area (Polloway, 2000). However, in recent years, this field received far less attention. Some authors (Tymchur, 2001; Fujiura, 2003) used the term the forgotten generation originally reference to adults with mild mental retardation; this concept underscores the relative paucity of attention to persons with mild intellectual disabilities.

The field of mild intellectual and developmental disabilities has witnessed the use of numerous terms to describe this population. Polloway (2006) noted: “... our lexicon has ranged from the use of the terms feebleminded and moron to mildly mentally handicapped, mildly mentally retarded, mildly mentally disabled, general learning disabilities, adaptive academic functioning deficits, (and) high incidence disability... "

For five decades, the most frequently used term was mental retardation. For example, it was the most frequent of the 66 terms found in the literature (Sandieson, 1998). Polloway et al. (2010) reported that 27 states used mental retardation for educational purposes. Bergeron et al. (2008) confirmed those findings as they reported this term was used by $53 \%$ of the states. Thus, while the filed continues to explore terminology, it is apparent that the implementation of these changes varies dramatically across the states.

As part of the ongoing discussion on terminology, a number of parallel questions have also been raised about the use of the term mild. Polloway (2006) noted that the mild concept has regularly created misconceptions within both the profession and the general population that has had implications for the eligibility of individuals for educational and other supports. Snell et al. (2009) referred instead to people with intellectual disabilities who have higher IQs. Nevertheless, mild continues to be used in the literature.

The term developmental delay is a federally designated label that refers to students under the age of 9 years who have experienced delay, or are identified as at risk for likely experiencing delay in the future, and are eligible for 
special education, subject to state guidelines. It has commonly provided an opportunity for the use of a less pejorative term by individuals assessing young children under consideration for eligibility who need to receive services without reference to the intellectual disability label. As such, it enables children to be served earlier in life who otherwise might have fallen through the cracks. In addition, the term is more functional and more service-related than the deficit-focused mental retardation.

Polloway et al. (2010) noted that changes in terminology can affect a number of areas. In schools, a name change may not be as important as which criteria are used to determine eligibility. In non-school settings it remains to be seen whether this group of individuals will be positively affected due to a shift of intellectual disabilities. A name change could have dramatic implications in the legal arena in which being diagnosed as mentally retarded is just beginning of to be understood, particularly in light of the attention given after the Supreme court decision in the Atkins case (Patton, 2006).

\subsection{Learning Disabilities}

Learning disabilities are the most common type of disability in the field of special education. Students with learning disabilities account for approximately half of all students receiving special education services in schools (Denton, 2003). As of 2010, this amounts to more than 3 million students with learning disabilities receiving special education or related services. Approximately $8 \%$ of all children, or $10 \%$ of boys and $6 \%$ of girls, between the ages 5 and 17 have had a learning disability diagnosis (Pastor, 2008). As a field, the area of learning disabilities is constantly growing and changing and it is one of the most active areas of special education research.

A learning disability (LD) is thought to be a neurological disorder that affects the brain's ability to receive, process, store, and respond to information (NCLD, 2007). The term learning disability is used to explain difficulty a person of at least average intelligence has in acquiring basic academic and functional skills. Learning disabilities can affect a person's ability to understand or use spoken or written language, do mathematical calculations, coordinate movements, or direct attention. These skills are essential for success at school or work, and for coping with life in general. Learning disabilities are caused by a difference in brain structure that is usually present at birth and is often hereditary.

Learning disabilities are not thought to be a reflection of intelligence. Instead, learning disabilities are generally associated with average or above average intelligence, but learning disabilities may occur together with mental or physical disabilities. Learning disabilities cannot be identified on the basis of vision or hearing acuity or other physical signs, nor can they be diagnosed solely based on neurological findings. Learning difficulties are generally regarded as variation on normal development and are only considered disabilities when they interfere significantly with school performance and adaptive functions. Estimates indicate that learning disabilities affect between $5 \%$ and $20 \%$ of the population (Pastor, 2008).

Recently, the American Psychiatric Association proposed the following definition for learning disabilities appeared in the Diagnostic and Statistical Manual V (DSM-V) (APA, 2013) in 2013: "A. A group of disorders characterized by difficulties in learning basic academic skills (currently or by history), that are not consistent with the person's chronological age, educational opportunities, or intellectual abilities. Basic academic skills refer to accurate and fluent and fluent reading, writing, and arithmetic. Multiple sources of information are to be used to assess learning, one of which must be an individually administered, culturally appropriate, and psychometrically sound standardized measure of academic achievement.

B. The disturbance in criterion A, without accommodations, significantly interferes with academic achievement or activities of daily living that require these academic skills."

The term learning disabilities have only been used since 1963, when Samuel Kirk, then professor of special education at the University of Illinois, used the term at a conference for parents and educators. Before Kirk's new term was introduced, terms such as "word blindness", "brain injured", "minimal brain dysfunction", or "perceptual handicap" were used to describe the same symptoms.

Learning disabilities can manifest in many different ways.

Reading disability is a language-based learning disability, also commonly called dyslexia. For most children with learning disabilities, reading is the primary area of difficulty. People with reading disabilities often have difficulties with spelling and decoding skills, usually rooted in a phonological processing deficit. They may also have problems recognizing words that they have already learned. Other symptoms of reading disability may include difficulties with comprehending text. Estimate indicates that between $5 \%$ and $20 \%$ of developed population have a learning disability, and $90 \%$ of those disabilities are related to reading (Gersten et al., 2001). 
Other language-related learning disabilities include problems that interfere with oral and written communication, including speaking, listening, reading, spelling, and writing. Learning disabilities related to writing may be called dysgraphia, which generally refers to difficulty in handwriting, such as forming letters or words or writing within a defined space. Other learning disabilities related to writing include difficulties with spelling, semantic memory, morphological awareness, grammatical structures, organizing information, putting thoughts on paper, or working memory (Beninger, 2009).

Learning disabilities related to math are sometimes called dyscalculia. Individuals with dyscalculia typically have difficulty understanding mathematical concepts and computation, sometimes even simple math problems. Math disabilities can include difficulties with spatial orientation, sequencing, and abstract concepts such as time and direction. In some individuals, a math disability may be linked to a concomitant reading disability, but in others math disabilities are more closely related to problems of working memory and problem solving (Swanson, 2009).

Some learning disabilities are related to the individual's ability to process and use the information that they acquire through their senses. This kind of problem is not related to any inability to see or hear, but they are instead related to the way the brain processes that sensory information. It may include difficulties with an individual's ability to process language, to understand what is heard or read, and to organize information. It may also include the speed with which the individual processes information and their attention, ability to retain information during problem-solving, and ability to self-monitor during learning. This type of learning disability is called an information processing disorder (Semrud-Clikeman, 2009).

\subsection{Attention-Deficit/Hyperactivity-Disorder (ADHD)}

Attention-Deficit/Hyperactivity Disorder (ADHD) is one of the most common disorders of childhood and, as of 2006, 4.5 million children have been diagnosed at some time with ADHD. ADHD is described as having "many faces", and as being "one of the most talked-about and controversial subjects in education", causing "heated debates" (Bloom, Cohen, 2006). To be consistent with the existing literature, the term "ADHD" will be used in this sub-chapter and will represent the full spectrum of attention disorders.

There has been great controversy surrounding the acceptance of ADHD as a "real" disorder, which is likely related to the lack of a definitive diagnostic test and the perceived overuse of stimulant medication with children. The National Institutes of Mental Health (NIMH, 2009) states that ADHD is one of the most common childhood disorders and can continue through adolescence and into adulthood and involves difficulty staying focused and paying attention, difficulty controlling behaviour, hyperactivity (overactivity). The U.S. Department of Education (U.S. DOE, 2009) states that ADHD is a neurological condition that involves problems with inattention and hyperactivity - impulsivity that are developmentally inconsistent with the age of the child and is a function on developmental failure in the brain circuitry that monitors inhibition and self-control.

However, most professionals use the APA diagnostics manuals, though some use the ICD-10 Classification system of the World Health Organization, which uses the term hyperkinetic disorder. In the most current edition, the DSM-V (APA, 2013), ADHD is defined as a persistent pattern of inattention and/or hyperactivity impulsivity that is more frequently displayed and more severe than is typically observed in individuals at a comparable level of development.

Because ADHD is such a constellation of characteristics, and the chance of the disorder co-existing with one or more disorders that also have sets of related characteristics, the manifestation of ADHD in a particular individual needs to be described across domains.

Characteristics associated with ADHD include distractibility, impulsivity, disorganization, emotional lability, risk-taking, depression, and anxiety. School failure, social problems, and task achievement can result in lower self-esteem, feelings of worthlessness, and more impulsive decision-making. Learning disabilities, conduct disorders, anxiety, oppositional defiant disorder, depression, bipolar disorder, Tourette Syndrome, sleep disorders, bed-wetting, and substance abuse may co-exist with ADHD (Barkley, 2005).

Behavioural Models. The criteria listed in the DSM-V describe many of the behaviours associated with ADHD, but a shift from the traditional view occurred when Barkley developed a paradigm that described a chronic lag of $30 \%-40 \%$ in the development of self-control and inhibition and presented a new construct using these descriptors. He recommended making inattention a separate category and proposed a theory of ADHD that has inhibition (which he refers to as the executive system that affects self-control and self-regulation) at the core. The new construct depicts the lag in inhibition (motor inhibition, sensitivity to error, interference control) as the first step in the system that impedes the development of the four executive functions: nonverbal working 
memory (includes time awareness or "time-blindness"), internalization of speech (includes emotional self-regulation), intrinsic motivation, and "play to yourself" (includes verbal fluency) (Barkley, 2005).

Adaptive behaviours. Low frustration tolerance, emotional lability, bossiness, temper outbursts, dysphoria, low self-esteem, laziness, and irresponsibility are features associated with ADHD. Teenagers with ADHD have more problems with driving and anger control (Richards, 2007).

The social manifestations of ADHD change across the lifespan. Peer rejection and negative imbalance between given and received liking ratings (children with ADHD liked others more than they were liked) discriminated children with ADHD from children without ADHD. Children with ADHD have fewer close friends and are rejected more often by their peers. Poor social functioning has also been found to be the best predictor of life dissatisfaction in college students with ADHD (Mrugs et al., 2009). Some studies reflect problems with sibling relationships as well as peers. Other studies focused on impaired interpersonal relationships for adults, and a growing body of literature is focused on the workplace and marital problems associated with ADHD (Wymbs et al., 2008).

\subsection{Emotional and Behavioural Disorders}

Children and youth with emotional and behavioural disorders present tremendous challenge to families, schools, and communities. Providing appropriate services to them challenges the capacity of both schools and communities, as educational, vocational, and mental health resources of many types and provided by many different service providers and agencies are often necessary to meet their typically chronic, often complex needs. These challenges are made greater by the nature of emotional and behavioural disorders (EBD), and by controversy surrounding most aspects of EBD. The nature of EBD is such that the behavioural characteristics of most students with EBD often make them unwelcome in social groups, unpopular among their peers, and potentially unwelcome in classrooms where their behaviour can be disruptive, disrespectful, unpleasant, and extraordinarily difficult for teachers to manage. In part because of the nature of EBD, the field is also characterized by controversy at nearly all levels. These include how to identify students with EBD; whether EBD is in fact a disability that can be distinguished from run-of-the-mill disruptive, aggressive, bad, or even delinquent behaviour; how and where students with EBD can be best served (i.e., where their educational needs can best be met); and how students with EBD can and should be disciplined (Landrum, 2011).

The ICD-10 classification has a category for conduct disorders (F91). The ICD-10 'Clinical Descriptions and Diagnostic Guidelines' states:

"... examples of the behaviours on which the diagnosis is based include the following: excessive levels of fighting or bullying; cruelty to animals or other people; severe destructiveness to property; fi re-setting; stealing; repeated lying; truancy from school and running away from home; unusually frequent and severe temper tantrums; defiant provocative behaviour; and persistent severe disobedience. Any one of these categories, if marked, is sufficient for the diagnosis, but isolated dissocial acts are not. "(WHO, 2005).

An enduring pattern of behaviour should be present, but no time frame is given and there is no impairment or impact criterion stated. The ICD-10 'Diagnostic Criteria for Research' differ, requiring symptoms to have been present for at least 6 months, and the introductory rubric indicates that impact upon others (in terms of violation of their basic rights), but not impairment of the child, can contribute to the diagnosis. The research criteria take a menu-driven approach whereby a certain number of symptoms have to be present. Fifteen behaviours are listed to be considered for a diagnosis of conduct disorder, which usually but by no means exclusively apply to older children and young people. The behaviours can be grouped into four classes:

a) Aggression to people and animals:

1. Often lies or breaks promises to obtain goods or favours or to avoid obligations

2. Frequently initiates physical fights (this does not include fights with siblings)

3. Has used a weapon that can cause serious physical harm to others (for example bat, brick, broken bottle, knife, gun)

4. Often stays out after dark despite parental prohibition (beginning before 13 years of age)

5. Exhibits physical cruelty to other people (for example ties up, cuts or burns a victim)

6. Exhibits physical cruelty to animals.

b) Destruction of property:

7. Deliberately destroys the property of others (other than by fi re-setting) 
8. Deliberately sets fires with a risk or intention of causing serious damage).

c) Deceitfulness or theft:

9. Steals objects of non-trivial value without confronting the victim, either within the home or outside (for example shoplifting, burglary, forgery).

d) Serious violations of rules:

10. Is frequently truant from school, beginning before 13 years of age

11. Has run away from parental or parental surrogate home at least twice or has run away once for more than a single night (this does not include leaving to avoid physical or sexual abuse)

12. Commits a crime involving confrontation with the victim (including purse-snatching, extortion, mugging)

13. Forces another person into sexual activity

14. Frequently bullies others (for example deliberate infliction of pain or hurt, including persistent intimidation, tormenting, or molestation)

15. Breaks into someone else's house, building or car.

To make a diagnosis, at least three behaviours from the 15 listed above have to be present, one for at least 6 months. There is no impairment criterion. There are three subtypes: 'conduct disorder confined to the family context' (F91.0), 'unsocialised conduct disorder' (F91.1, where the young person has no friends and is rejected by peers) and 'socialised conduct disorder' (F91.2, where peer relationships are normal). It is recommended that age of onset be specified, with childhood-onset type manifesting before 10 years and adolescent-onset type after 10 years. Severity should be categorised as mild, moderate or severe according to the number of symptoms or impact on others, for example causing severe physical injury, vandalism or theft (WHO, 2016).

For younger children, usually up to 9 or 10 years old (although it can in theory be used up to 18 years), there is a list of eight symptoms for the subtype known as 'oppositional defiant disorder' (F91.3):

1. has unusually frequent or severe temper tantrums for his or her developmental level

2. Often argues with adults

3. Often actively refuses adults' requests or defies rules

4. Often, apparently deliberately, does things that annoy other people

5. Often blames others for his or her own mistakes or misbehaviour

6. Is often 'touchy' or easily annoyed by others

7. Is often angry or resentful

8. Is often spiteful or resentful.

To make a diagnosis of the oppositional defiant type of conduct disorder, four symptoms from either this list or the conduct disorder 15-item list must be present, but no more than two from the latter. Unlike for the conduct disorder variant, there is an impairment criterion for the oppositional defiant type: the symptoms must be maladaptive and inconsistent with the child or young person's developmental level. Where there are sufficient symptoms of a comorbid disorder to meet diagnostic criteria, ICD-10 discourages the application of a second diagnosis, and instead offers a single, combined category for the most common combinations. There are two major kinds: mixed disorders of conduct and emotions, of which depressive conduct disorder (F92.0) is the best researched; and hyperkinetic conduct disorder (F90.1). There is modest evidence to suggest these combined conditions may differ somewhat from their constituent elements. DSM-V follows the ICD-10 research criteria very closely and does not have separate clinical guidelines. The same 15 behaviours are given for the diagnosis of conduct disorder (312.8, American Psychiatric Association, 2000), with almost identical wording. As in ICD-10, three symptoms need to be present for diagnosis. Severity and childhood or adolescent onset are also specified in the same way. However, unlike ICD-10, there is no division into socialised/unsocialised or family context, only into types, and there is a requirement for the behaviour to cause 'clinically significant impairment in social, academic, or social functioning'. Comorbidity in DSM-IV-TR is handled by giving as many separate diagnoses as necessary, rather than by having single, combined categories. In DSM-V, oppositional defiant disorder is classified as a separate disorder, not as a subtype of conduct disorder. Diagnosis requires four from a list of eight behaviours, which are the same as ICD-10; but, unlike ICD-10, all four have to be from the oppositional list and none may come from the conduct disorder list. In older children it is debated whether oppositional defiant disorder is fundamentally different from conduct disorder in its essential phenomena or any 
associated characteristics, and the value of designating it as a separate disorder is arguable. In this guideline, the term 'conduct disorders' will henceforth be used as it is in ICD-10, to refer to all variants including oppositional defiant disorder.

\subsection{Communication Disorders}

There are two types of communication disorders: Those that affect speech (speech disorders) and those that affect language (language disorders). Problems producing speech sounds (articulation), controlling sounds that are produced (voice), and controlling the rate and rhythm of speech (fluency) are generally considered speech disorders. Problems with using proper forms of language (phonology, morphology, syntax), using the content of language (semantics), and using the functions of language (pragmatics) are generally considered language disorders (Goldin-Meadow, 2003).

\subsubsection{Speech Disorders}

The American Speech-Language-Hearing Association (ASHA) has developed formal definitions of each speech disorder:

Articulation disorder is defined as "the abnormal production of speech sounds". When a student says, "The wabbit wan don the woad," or "poon" for "spoon," orLEI "gog" for "dog," he or she may be using spoken language appropriately but is not producing sounds correctly. Voice disorder is defined as "the absence or abnormal production of vocal quality, pitch, loudness, resonance, and/or duration". Students with voice disorders sometimes sound hoarse or speak loudly or in a high or low pitch. Fluency disorder is defined as "the abnormal flow of verbal expression, characterized by impaired rate and rhythm which may be accompanied by struggle behaviour". S-saying th-the f-first s-sound o-of a-a w-word and th-then s-saying th-the w-word illustrates this problem (Levelt, 1993).

\subsubsection{Language Disorders}

All other communication problems are considered language disorders. There are three kinds of language disorders - specifically, problems related to form, content, and function. Language form refers to the utterance or sentence structure of what is said - phonology, morphology, and syntax. Language content refers to meanings of words and sentences, including abstract concepts - semantics. Language function refers to the context in which language can be used and the purpose of communication-pragmatics. Problems can be receptive (related to hearing, listening to, or receiving language) and expressive (related to producing or expressing language) (Adams, 2006).

\subsubsection{Language Form, Function, and Content}

Phonology is concerned with the smallest units of language (phonemes or speech sounds); morphology is concerned with the smallest units of meaningful language (morphemes or words and parts of words); and syntax is concerned with combining language units into meaningful phrases, clauses, or sentences (grammatically correct language). Problems with phonology, morphology, and syntax are evident when students are unable to differentiate sounds (/b/ versus /p/), words (cat or cap), or grammatically correct sentences ("John go to the movies" versus "John goes to the movies") or to produce appropriate sounds, words, or sentences. Semantics is concerned with word and message meanings (vocabulary, comprehension, following directions). Problems with semantics are evident when students are unable to identify appropriate pictures when word names are provided ("Find the grapes"), answer simple questions ("Are apples fruits?"), follow directions ("Draw a line over the third box"), tell how words or messages are similar or different ("How are apples, oranges, and pears alike?"), or understand abstract concepts ("What is love?"). Pragmatics is concerned with the use and function of language in varying settings (i.e., following social conversational rules). Problems with pragmatics are evident when students are unable to use language in social situations to express feelings, create or understand images, give or request information, or direct actions of listeners (Levelt, 1993).

\subsection{Auditory Impairment}

Hearing loss is considered to be the most prevalent congenital abnormality in new-borns and is more than twice as prevalent as other conditions that are screened for at birth, such as sickle cell disease, hypothyroidism, phynilketonuria, and galactosaemia. (. It is one of the most common sensory disorders and is the consequence of sensorineural and/or conductive malfunctions of the ear. The impairment may occur during or shortly after birth (congenital or early onset or may be late onset) caused post-natal by genetically factors, trauma or disease. Hearing loss may be pre-lingual (i.e., occurring prior to speech and language acquisition) or post-lingual (i.e., occurring after the acquisition of speech and language) (Karchmer, Mitchell, 2003). 
Since hearing loss in infants is silent and hidden, great emphasis is placed on the importance of early detection, reliable diagnosis, and timely intervention. Even children who have mild or unilateral permanent hearing loss may experience difficulties with speech understanding, especially in a noisy environment, as well as problems with educational and psycho-social development. Children with hearing loss frequently experience speech-language deficits and exhibit lower academic achievement and poorer social-emotional development than their peers with normal hearing (Leigh, 2009).

The period from birth to 3-5 years is often considered as the "critical period" for the development of normal speech and language. Normal hearing in the first six months of life is also considered critical for normal speech and language skills. Hence, early identification and appropriate intervention within the first six months of life have been demonstrated to prevent or reduce many of the adverse consequences and to facilitate language acquisition. Consequently, in developed countries with a high standard of health care, primary services include the early detection of congenital hearing loss and the initiation of auditory habilitation before six months of age (Langh, 2002).

The prevalence of congenital and early-onset hearing loss in most developed countries is estimated to range between 2-4 infants with moderate-severe hearing loss in every 1000 births. In contrast, only limited information is available on developing regions, including the Middle East especially in the Arab countries, where the prevalence is estimated to be markedly higher than in Israel or European and North American countries. In developing countries, more than 10 infants in every 1000 births are estimated to be affected by a severe profound hearing loss. Of the 62 million deaf children younger than 15 years old worldwide, two-thirds reside in developing countries (Leigh, 2009).

Presbycusis (age-related hearing loss) is the loss of hearing that gradually occurs in most individuals as they grow older. Hearing loss is a common disorder associated with aging and is ranked as the third most prevalent chronic condition in elderly people after hypertension and arthritis. Its prevalence and severity increase with age, rising from about 30-35 percent of adults aged 65 and older to an estimated 40-50 percent of adults aged 75 and older. The loss associated with presbycusis is usually greater for high-pitched sounds. For example, it may be difficult for someone to hear the nearby chirping of a bird or the ringing of a telephone, and it is most difficult to understand speech in a noisy background. However, the same person may be able to clearly hear the low-pitched sound of a truck rumbling down the street. Presbycusis most often occurs in both ears, affecting them equally. Because the process of loss is gradual, people who have presbycusis may not realize that their hearing is diminishing.

Presbycusis is described four types of human:

1. sensory, mainly affecting the cochlear hair cells and supporting cells

2. neural, typified by the loss of afferent neurons in the cochlea

3. metabolic, where the lateral wall and stria vascularis of the cochlea atrophy; and

4. mechanical, where there seemed to be a so-called "stiffening" of the basilar membrane and organ of Corti

There are many causes of presbycusis, though it is most commonly the result of changes in the inner ear as a person ages. It can also stem from changes in the middle ear or from complex changes along the nerve pathways leading to the brain (Christensen, Leigh, 2002).

The negative impact of hearing loss on older adults is significant. Hearing loss is associated with depression, social isolation, poor self-esteem, and functional disability, particularly for those suffering from hearing impairment who have not yet been evaluated or treated for hearing loss.Hearing impairment is a broad term that refers to hearing losses of varying degrees, ranging from hard-of-hearing to total deafness. As the general population continues to age, the prevalence of hearing impairment can be expected to increase. Since the use of hearing aids or surgical intervention to improve hearing loss has been shown to have a positive impact on quality of life, more screening programs for elderly adults should be established, followed by appropriate referral to audiologists based on individual needs. Without early diagnosis and treatment of hearing impairment, quality of life and functional status are likely to decline in the aging population. The major challenge facing people with hearing impairment is communication. Hearing-impaired persons vary widely in their communication skills. Among the conditions that affect the development of communication skills by persons with hearing impairments are personality, intelligence, nature and degree of deafness, degree and type of residual hearing, degree of benefit derived from amplification by hearing aid, family environment, and age of onset. Age of onset plays a crucial role in the development of language. Persons with pre-lingual hearing loss (present at birth or occurring before 
the acquisition of language and the development of speech patterns) are more functionally disabled than those who lose some degree of hearing after the acquisition of language and speech (Leigh, 2009).

\subsection{Visual Impairment}

\subsubsection{Categories of Visual Impairments}

Categories of visual impairments reflect more than just visual acuity. Students' ability to use vision, as well as how much they use other senses for learning, are aspects of each category. The terms low vision, functionally blind, and blind are often used to describe and categorize levels of vision. Each category is considered in terms of the degree of acuity and its implications for students' learning.

\subsubsection{Low Vision}

Generally, students with low vision are able to learn using their visual sense; however, they may need to have print magnified, contrast enhanced, or type font or size changed. Students in this category characteristically work more slowly and experience difficulty working with details (Schwartz, 2010).

\subsubsection{Functional Blindness}

People with functional blindness typically use a combination of modalities to function within their surroundings. Students in this category generally read and write using Braille. Some functionally blind individuals have sufficient vision to allow them to move around the classroom safely. Others, however, may require considerable accommodations to do so (Schwartz, 2010).

\subsubsection{Blindness}

Near blindness and total blindness are included in this category. Near blindness occurs when visual acuity is reduced so greatly that learning takes place using data from other senses most of the time. Students with total blindness receive no stimuli from their visual channel. They depend entirely on input from other senses (Schwarz, 2010).

\subsection{Autism Spectrum Disorders}

Autism Spectrum Disorder (ASD) is an early onset, pervasive, and lifelong neurodevelopmental disorder characterized by challenges in social communication and repetitive, restricted behaviour patterns and atypical response to sensory stimuli. Since the first published description of autism (Kanner, 1943), estimates of prevalence have dramatically increased, with current estimates indicating 1 in 68 individuals in the United States are diagnosed with ASD. Although biases in access to care may exist, ASD is evident in all racial, ethnic, and socioeconomic groups (Centers for Disease Control, 2014).

\subsubsection{Clinical Characteristics}

Autism is currently conceptualized as a spectrum disorder, reflecting significant phenotypic and genotypic heterogeneity, including considerable variability in intellectual and communicative ability. Its developmental impact is pervasive, spanning multiple domains of function and leading to impairment in multiple aspects of adaptive functioning. Individuals with ASD require various levels of support with their daily living, ranging from needing continual care to being fully independent. The unifying diagnostic features of ASD are persistent impairments in social communication and restricted, repetitive behaviours and atypical sensory behaviour (Abrahams, 2008).

\subsubsection{Social Communication}

Individuals with autism display deficits in (1) socio-emotional reciprocity. They may seem to lack interest in or struggle with sustained social interactions. For example, they may be unable to initiate conversation or may have one-way conversations about topics of their own interest. They also demonstrate (2) deficits in nonverbal communication. For example, they may have poor eye contact or difficulty understanding body language and facial expressions. In addition, individuals with autism (3) have difficulty maintaining relationships. For example, they may seem to lack interest in making friends or have difficulty adjusting their behaviours to match different social situations (APA, 2013).

\subsubsection{Restricted, Repetitive Behaviours}

Individuals with ASD also demonstrate at least two patterns of restricted, repetitive behaviours. They may (1) have repetitive movements or language, such as lining up toys or repeating a phrase at unusual times. Alternatively, they may (2) display behavioural rigidity such as experiencing extreme distress to small changes. Furthermore, individuals with autism may (3) have restricted interests that are abnormal in intensity or focus. Additionally, they may (4) display unusual sensory reactivity. For example, they may strongly attempt to avoid specific textures and 
sounds, or appear indifferent to physical pain (APA, 2013).

\subsubsection{Other Clinical Features}

Finally, in order to receive a diagnosis of autism, behaviours must not be primarily explained by intellectual disability or global developmental delay; however, associated intellectual disability is common. Individuals with autism also have elevated comorbidities with other psychiatric disorders such as attention deficit hyperactivity disorder, depression, and anxiety, as well as other medical conditions, such as seizures and gastrointestinal problems. Other common features of ASD that are not required for diagnosis include motor deficits, self-injurious behaviours, and catatonia (Sullivan, 2014).

\subsection{Severe and Multiple Disabilities}

Individuals with severe disabilities and multiple disabilities (SMD) are highly diverse in both their abilities and disabilities. What they share is a capacity to learn and a lifelong need for support. Students with SMD have a combination of two or more impairments such as movement difficulties (e.g., cerebral palsy), intellectual disabilities, sensory losses (e.g., vision or hearing loss), and/or behavioural learning difficulties. These impairments are of a severe nature requiring systematic, long-term curricular instructional, and environmental accommodations and support (Collins, 2007).

\subsubsection{Definition and Types of Severe and Multiple Disabilities}

Persons with severe disabilities are: "individuals of all ages who require extensive ongoing support in more than one major life activity in order to participate in integrated community settings and to enjoy a quality of life that is available to citizens with fewer or no disabilities". Mental retardation is regarded as a characteristic common to those with severe disabilities. Most severely disabled individuals are limited in their ability to communicate, though these skills can become functional with appropriate intervention. In addition, these individuals often have medical conditions or physical limitations that affect their movement, vision, or hearing (Collins, 2007).

Persons with multiple disabilities have a combination of two or more serious disabilities (e.g., cognitive, movement, sensory), such as mental retardation with cerebral palsy. The U.S. federal government definition includes those who have more than one impairment, "the combination of which causes such severe educational needs that they cannot be accommodated in special education programs solely for one of the impairments. (Dual sensory impairment, or deaf-blindness, is defined as a separate disability group.) Multiple disabilities have interactional, rather than additive, effects, making instruction and learning complex. These physical and medical problems result in the presence of two or more of the following characteristics: restriction of movement, skeletal deformities, sensory disorders, seizure disorders, lung and breathing control, or other medical problems related to these characteristics, such as skin breakdown or bladder infections (Collins, 2007).

The two groups overlap somewhat in definition. Multiple disabilities, depending upon the definition used, may or may not include mental retardation as one disability, while severe disabilities requires mental retardation but does not require an additional disability. Some movement disabilities are associated with mental retardation; for example, 60 to 70 percent of those with cerebral palsy have some degree of mental retardation. However, a child with cerebral palsy who does not meet the cognitive requirements of mental retardation might fit the federal definition of multiple disabilities, due to having movement and communication disabilities, but not the definition of severe disabilities. Most individuals who have multiple disabilities also fit the criteria for severe disabilities, while not all with severe disabilities have multiple disabilities (Cloninger, 2007).

The primary measures used to diagnose these individuals are individual intelligence tests and tests of adaptive behaviour. Early assessment of movement limitations, muscle tone and flexibility, seizure activity, breathing control, sucking and swallowing, vision and hearing, and genetic makeup are also, and prenatal assessment of genetic material or physical identification of deformities via sonograms may be conducted. Accurate psychological testing of these individuals is challenging due to their frequent limitations in controlled movement, vision, hearing, communication, or cooperative behaviour. Thus, interviews with family members and educators regarding the person's adaptive behaviour skills (i.e., communication, self-care, home living, social skills, community use, self-direction, health and safely, functional academics, leisure, and work) may be more informative and reliable than a norm-based IQ or achievement score (Cloninger, 2007).

Definitions of this highly variable group with both severe and multiple disabilities are less precise than some other disability groups, making an estimate of their prevalence difficult. Prevalence ranges from less than .25 percent to .50 percent of the population; and is considered relatively uniform across socioeconomic classes.

Persons with severe and multiple disabilities may carry a variety of diagnostic labels, including:(1) severe or profound levels of mental retardation (IQ scores below 40); (2) mental retardation that requires extensive or 
pervasive supports for an extended time; (3) autism, childhood disintegrative disorder, or Rett syndrome (several types of autism spectrum disorders); and (4) various genetic disorders accompanied by extensive mental retardation (e.g., Tay-Sachs disease, untreated phenylketonuria, tuberous sclerosis, Lesch-Nyhan syndrome). Individuals with several autism spectrum disorders, by definition, have significant developmental delays in communication and social interaction, and may exhibit extensive limitations in many adaptive skills. Thus, their disability may be extensive enough to fit the definition for mental retardation and severe disabilities, though this is not true for all persons identified with autism (e.g., Asperger's syndrome) (Collins, 2007).

\subsection{Special Gifts and Talents}

Thirty and more years ago when "giftedness" was defined by an IQ score, a school district simply set an arbitrary score (usually in the 130 range) and a student either did or did not "make the cut". Although it is no longer accepted today in academic circles, it is still used by many school districts, no doubt, because it is simple and not entirely without merit. Now that the concept is generally more broadly conceived than before, there is no single accepted definition of giftedness. Correspondingly, there is no dearth of definitions either! Before considering some of the current definitions in wide circulation today, it may be appropriate to go back momentarily to the IQ based one. Although a high IQ may have fallen out of favour as a measure to define giftedness, the fact remains that, if a student has a very high IQ, it is significant indicator, indeed the single most important one, of a student's academic potential. It is not meaningless or trivial. Correspondingly, if a student scores highly on an IQ test, but performs at an average or below average level academically, this warrants further investigation. Several of the more common definitions in use today are presented below:

Gifted and talented children are those identified by professionally qualified people, who by virtue of outstanding abilities are capable of high performance. These are children who require differentiated educational programs and/or services beyond those normally provided by the regular school program in order to realize their contribution to self and society. Children capable of high performance include those with demonstrated achievement and /or potential ability in any of the following areas, singly or in combination:

- general intellectual ability

- specific academic aptitude

- creative or productive thinking

- leadership ability

- visual and performance arts

- psychomotor ability (later removed in 1997) (Gross, 2008)

This would be termed an "omnibus" definition because it specifies a broad range of areas of giftedness, as well as potential, in each. Although it is more than 30 years old, and is seen by some as problematically broad, it remains popular and has been adopted, as is or slightly modified.

Another omnibus definition is that of Abraham Tannenbaum who states that: "Giftedness in children denotes their potential for becoming critically acclaimed performers or exemplary producers of ideas in spheres of activity that enhance the moral, physical, emotional, social, intellectual, or aesthetic life of humanity". Whether a child actually develops her potential and develops into a stellar producer or performer depends on a number of factors and life circumstances (Tannenbaum, 1985).

\subsubsection{Definitions}

Until time runs its course, the most that can be said using this model (and several others) is that a child has the potential to be gifted. Another well-known definition and model is Renzulli's three ring conception of giftedness which he depicts as three concentric rings representing above average ability, task commitment and creativity.

Giftedness is an interaction among three basic clusters of human traits: above average ability, high levels of task commitment, and high levels of creativity. Gifted children either possess or are capable of developing these traits and applying them to any valuable area of human performance (Renzulli, 2005).

It has been wisely note that this does not imply that a student must possess all of the three rings to be considered for inclusion in a program for gifted students. For example, a student may be included without knowing his IQ. Correspondingly, a student may be known to have a high IQ, but may not work up to potential.

Most teachers, indeed even people outside the field of education, are familiar with Howard Gardner's Theory of Multiple Intelligences. Gardner believes that each of these have a neurological basis; have a unique set of core operations; each has its own symbol system, for example, language, numerals, musical notation; while some are 
correlated with others (math and music), most have low correlations. The intelligences are as follows:

\section{Linguistic - Ability to learn and use language effectively}

2. Logical-mathematical - Skill at mathematics, numerical patterns and logical reasoning

3. Spatial - the ability to think in pictures, to perceive the visual world accurately, and recreate (or alter) it in the mind or on paper

4. Musical - the ability to understand and create music

5. Bodily-kinaesthetic - the ability to use one's body in a skilled way, for self-expression or toward a goal

6. Interpersonal - an ability to perceive and understand other individuals - their moods, desires, and motivations

7. Intrapersonal - an understanding of one's own emotions

8. Naturalistic - the ability to recognize and classify various elements of nature, or to create something that is valued in one or more cultures (Gardner, 1983).

Gardner's MI theory has been widely accepted by educators, probably because it "makes sense" and is consistent with people's experience in their personal interactions, both in and outside of school. For example, a teacher meets a "so-so" student several years out of school who is a highly successful jazz musician. It is also consistent with our desire to see giftedness in all students, or as one author put it, "Mother Nature is egalitarian after all." However, it should be emphasized that Gardner himself does not claim that all students are gifted. Gardner's theory has come under criticism, however, on a number of counts. More than ten years after it was introduced, it has yet to be firmly grounded in research. Some claim it is faddish (Gross, 2008).

An interesting phenomenon, relative to the gifted (especially the highly gifted) is noteworthy. While lower ability students tend to be low in all mental abilities, high ability students are not as likely to be uniformly high. The higher the ability, the more likely this is to so. Thus, Einstein, while a great mathematician, was not a playwright; nor was Shakespeare a great scientist. Whether abilities exist independently or not, schools will never be able to address their development equally or adequately. Indeed we struggle sometimes with just the first two. What schools can do, though, is expose students to others, create awareness and appreciation and play an advocacy role for students with particular talents in areas such as fine arts, or athletic ability.

A final definition is Francoys Gagne's model of giftedness, which he terms The Differentiated Model of Giftedness and Talent. Gagne's definition is distinct in that it clearly distinguishes between giftedness and talent. Defined by Gagné, giftedness is the possession and use of untrained and spontaneously expressed natural abilities, in at least one ability domain, to a degree that places an individual in at least the top 10 percent of age peers. He identifies 4 domains representing giftedness: intellectual, creative, socio-affective and sensorimotor. Talent designates the superior mastery of systematically developed abilities or skills and knowledge in at least one field of human activity to a degree that places an individual at least among the top 10 percent of age peers who are active in that field. These skills include: academics, arts, business, leisure, social action, sports and technology. Catalysts (either positive or negative) for their development include milieu, people, provisions and events (Gagné, 2005).

\section{Possibilities of Inclusive Education of Students With Special Educational Needs}

Inclusive education of pupils with special educational needs is not a new concept in many of school systems abroad. In the Slovak republic, inclusive education of students with special educational needs has been on the increase since 1990, and it is facing many challenges. Preparedness of teachers for inclusive education is one of the most frequent issues; teachers lack skills when it comes to the use of effective instruction depending on individual needs of students, improvement of classroom management and social skills, and support of inclusion within the classroom (hrebeňárová et al. 2016). At present, every teacher must be prepared for considerable heterogeneity of students in his/her classroom. Starting point of each teacher and educational professional in inclusive education is to follow state legislation and core principles that forms basis of policy and practice for the inclusion of students with special educational needs. For achieving school success of students with special educational needs the whole process of inclusive education must be supported by trained general education teachers, prepared environment, evidence and research based practices.

Inclusion is seen as a process of addressing and responding to the diversity of needs of all learners through increasing participation in learning, cultures and communities and reducing exclusion within and from education. It involves changes and modifications in content, approaches, structures and strategies, with a common vision which covers all children of the appropriate age range and a conviction that it is the responsibility of the regular system to educate all children (UNESCO, 2005). 
There are many benefits of placement students with special educational needs in general education, for example peers can serve as role models, friendship are naturally developed in the student's home community, social skills are developed in the natural environment, students without disability learn to value diversity, additional resources in general classrooms can benefit all students. Of course, these benefits are found in general education programs with well-trained teachers who value collaboration, provide services necessary for student success, and carefully monitor the educational outcomes of students with and without disabilities (White, Duffy, 2014).

UNESCO views inclusion as a dynamic approach of responding positively to pupil with diversity and seeing individual differences not as problems, but as opportunities for enriching learning. Therefore, the move towards inclusion is not simply a technical or organizational change but also a movement with a clear philosophy. In order for inclusion to be implemented, countries need to define a set of inclusive principles, practical ideas to guide the transition towards policies addressing inclusion in education (UNESCO, 2005).

There are many of principles that have formed the basis of policy and practice for the inclusion of students with special educational needs. School systems have used these principles to develop system-wide policies, school leaders have used them as a basis for school policy and practice, and classroom teachers have used them in the preparation and implementation of educational programs (Foremann, 2011). At the core of inclusive education is the human right to education, pronounced in the Universal Declaration of Human Rights in 1948. Equally important are provisions of the Convention on the Rights of the Child. Right-based approach to education is founded upon three principles - access to free and compulsory education; equality, inclusion and non-discrimination; the right to quality education, content and processes (UNESCO, 2005).

Article 26 of the Universal Declaration of Human Rights (UN, 1948)

"Everyone has the right to education. Education shall be free, at least in the elementary and fundamental stages. Elementary education shall be compulsory. Technical and professional education shall be made generally available and higher education shall be equally accessible to all on the basis of merit. Education shall be directed to the full development of the human personality and to the strengthening of respect for human rights and fundamental freedoms."

Article 23 of the Convention on the Rights of the Child (UN, 1989)

"Recognizing the special needs of a disabled child, assistance extended in accordance with paragraph 2 of the present article shall be provided free of charge, whenever possible, taking into account the financial resources of the parents or others caring for the child, and shall be designed to ensure that the disabled child has effective access to and receives education, training, health care services, rehabilitation services, preparation for employment and recreation opportunities in a manner conducive to the child's achieving the fullest possible social integration and individual development, including his or her cultural and spiritual development."

Table 2. Core human rights obligation in education

\begin{tabular}{ll}
\hline Availability & $\begin{array}{l}\text { Obligation to ensure compulsory and free education for all children } \\
\text { Obligation to respect parental freedom to choose education for their children }\end{array}$ \\
\hline Accessibility & $\begin{array}{l}\text { Obligation to eliminate exclusion from education based on discrimination (race, sex, } \\
\text { language, religion, opinion, economic status, birth, social status, minority and disability) }\end{array}$ \\
Acceptability & $\begin{array}{l}\text { Obligation to set minimum standards for education, including the medium of instruction, } \\
\text { contents and methods of teaching, and to ensure their observance in all educational institutions }\end{array}$ \\
Adaptability & $\begin{array}{l}\text { Obligation to adapt education to the best interests of each child, especially regarding children } \\
\text { with } \\
\text { disabilities, or minority and indigenous children }\end{array}$ \\
\hline
\end{tabular}

(Source: own processing based on Tomasewski, 2004)

Implementing inclusion requires changes of school and educational systems, and this change process is frequently faced with several challenges. One of the most frequent issues of inclusive education in Slovakia is the insufficient preparedness of teachers for inclusive education, lack of skills mainly in the area of individualized education plan development, use of special methods and procedures, and diagnostic skills (Mandzáková, Pitoňáková, 2005; Hrebeňárová, Mandzáková, 2007), and unpreparedness of schools for inclusive education of students with more severe, or multiple, disabilities (Hrebenárová, 2013). Žolnová (2014) notes that the preparedness of teachers is conditional upon the changing approach in the preparation of undergraduate students. 
Reforming the school systems to become inclusive is not only about putting in place recently developed inclusive policies that meet the needs of all learners, but also about changing the culture of classrooms, schools, school districts and universities etc. Change process towards inclusion involves some obstacles such as existing attitudes and values, lack of understanding, lack of necessary skills, limited resources, inappropriate organization. Key elements in the shift towards inclusion are clarity of purpose, realistic goals, motivation, support, resources and evaluation (UNESCO, 2005).

In effective teaching of students with special educational needs teachers must plan what to teach and how to teach all students in inclusive settings. Planning of teaching must require selecting appropriate content of teaching and level of understanding the content through measurable and observable goals and objectives. Teacher must also focus precisely on different strategies of motivation different types of students in the classroom and how will make the information and learning for students meaningful. Planning for teaching must be individualized and based on differentiations between students' abilities, specific needs and educational content.

According to Kauffman et al. (2011) individualized planning based on use of empirically based effective practices is a prerequisite for success. It is obvious that a possible explanation for the relatively poor outcomes of many students with special educational needs in inclusive settings is that their inclusion-based education has been woefully lacking in methods that have been objectively vetted in a variety of typical general education classrooms.

Orkwis and McLane (1998) suggest incorporating multiple methods of presenting information and multiple methods of student's response and engagement:

Presenting information: when presenting information in a lesson, plan to say, demonstrate or write the information. This redundancy of information will allow students with special educational needs to access and benefit from the information. While using visual support in lessons or activities, provide verbal descriptions or written captions for audio materials.

Student responses: when asking students to express their learning, include every student by providing alternatives, such as saying or recording, writing, typing, drawing, or demonstrating the response. Word-processing programs provide students with many supports, such as grammar and spelling checks. Students who are unable to make oral presentations may create multimedia presentations, or supply computer graphic as an alternative to hand drawing. Teacher can decide who will select the response type for students, so not only student will able to freely choose the type of response.

Student engagement: keep students engaged in learning by providing variety in supports or scaffolds, which will help challenge individuals appropriately. Techniques for maintaining students engagement include planning various student groupings (for example, skills group, partner group, peer tutoring), using a variety of lesson models, incorporating student's interests into lessons or activities, helping students to understand the value of what they are learning and how it applies to life outside the school.

To maximize the success of students with special educational needs in inclusive settings Mastropieri and Scruggs (2007) recommend using the PASS variables. They represent a way of thinking and approaching instructions for including students with disabilities in general education classrooms, and stands for:

P-Prioritize objectives; determine which are the most important for students with disabilities and eliminating objectives that are unnecessary for those students.

A-Adapt instruction, materials, or environment to accommodate more the needs of students with disabilities.

S-Use systematic instruction variables during instruction; such as structure, clarity, redundancy, enthusiasm, appropriate rate, and maximizing engagement through questioning and feedback.

S-Implement systematic evaluation procedures as frequently as possible of students' progress toward meeting the instructional objectives of the class, as well as IEP objectives.

\section{Conclusion}

Naturally, there are not only pros and benefits rising from inclusive education. There are also opinions against the inclusion.

Those who oppose inclusion typically emphasize one or more of the following beliefs. Some dissenters believe that advocates of inclusion who base their support on philosophical and moral grounds are wishful in their thinking and instead should base their judgements on empirical evidence. Attempts to link non-inclusion practices with apartheid and slavery lack evidence, are emotional in nature, and do not benefit the educational process (Price, Nelson, 2007). Some research confirms the belief that many pupils need more intense instruction 
and support than is provided in mainstream classrooms (Kaufman et al. 2011).

The belief that all children can learn has been described as naïve liberalism (Foreman, 2011). Foreman believes that the broad scale use of inclusion is fallacious and contends that efforts by courts to support inclusion arise from a desire to emphasize the promotion of social goals consistent with the least restrictive environment rather than promoting suitable academic environments. Also, he believes the fundamental purpose of the education system is to foster learning, not socialization (Foreman, 2011).

Dissenters of inclusion point to difficulties encountered by teachers attempting to meet the needs of diverse pupils, especially those with moderate and severe disabilities (Hlebová et al., 2015). Many of them are not prepared for these responsibilities. Some teachers utilize classroom peers to provide needed instruction even though they are untrained and ill prepared (Cloninger, 2007). In some locations, teacher contracts allow them to decide which types of disabilities and the number of pupils with disabilities they will accept in their classrooms.

Standard education teachers often feel unprepared and thus lack confidence in their abilities to teach pupils with disabilities or impairments. Some dissenters of inclusion argue against the idea that good teachers can teach all pupils and that standard education classroom can be successful in managing all pupils without some form of administrative differentiation (Groven, 2015). Those who advocate for full inclusion may not place much importance on research evidence and instead focus on issues of compassion and caring.

Teachers may respond to the diversity when planning instruction by adding drama, humor, novelty, or excitement to gain attention; personalizing instruction by using students names or experiences; in opening, involving students who are most difficult to motivate or focus; increasing time spent on the review of earlier lessons or prerequisite skills and knowledge; involving everyone in active responses (for example, have all students write the definition of term from yesterday's lesson rather than asking "Who remembers what this means?"); telling students to write or say something they already know about a topic in three minutes. Teacher must carefully consider each students background knowledge and do not make assumptions. Also students from culturally different background bring different knowledge and experience to the topic (Price, Nelson, 2007).

School systems provide wide range of educational placements for students with special educational needs, from the least to the most restrictive. Parents of students with special educational needs must have the opportunity to choose the best placement for their child according to child's individual needs and recommendation of special education teacher and professionals from related services. To provide effective inclusive education teachers and other professionals must follow national legislation and policy of inclusive practices, core human rights obligation in education as well as basic principles underlying inclusion and inclusive education, such as normalization, social justice and human rights, the least restrictive environment, all children can learn and age appropriate education.

\section{Acknowledgements}

Study is the partial outcome of the research project APVV-15-0071 Man with handicap in the literature for children and youth (2016-2020).

\section{References}

Abrahams, B.S. (2008). Advances in autism genetics. On the thereshold of new neurobiology. Nature Reviews Genetics, 9, 341-355. https://doi.org/10.1038/nrg2346

Adams, L. (2006). Group treatment for Asperger syndrome: A social skill curriculum. San Diego, CA: Plural, 2006.

American Psychiatric Association. (2013). Diagnostic and Statistical Manual of Mental Disorders (5th ed.).

Barkley, R.A. (2005). ADHD and the nature of self-control. New York: Guilfrod

Beninger, V. (2009). Assessing and intervening with children with written language disorders. Best Practices in School Neuropsychology, 507-520. New York: Wiley.

Bergeron, R. (2008). States' eligibility guidelines for mental retardation: An update and consideration of part scores and unreliability of IQs. Education and Training in Developmental Disabilities, 43, 123-131.

Bloom, B., \& Cohen, R.A. (2006). Summary of health statistics for US children: National health interview survey. National Centre for Health Statistics-Vital Health Statistics, 10, 234.

Center for Disease Control. (2014). Prevalence of autism spectrum disorders among 8 years- autism and developmental disabilities monitoring network. Morbidity and Mortality Weekly Report, 63, 11.

Christensen, J., \& Leigh, I. (2002). Cochlear implantants in children: Ethics and choices. Washington, D.C.: 
Gallaudet University Press.

Cloninger, C.J. (2007). Designing collaborative educational services (4th ed.). In Educating children with multiple disabilities: A collaborative approach. Baltimore: Brookes.

Collins, B.C. (2007). Moderate and severe disabilities: A foundational approach. Upper Saddle River, NJ: Pearson.

Convention on the Rights of the Child. (1989). Adopted and opened for signature, ratification and accession by General Assembly resolution 44/25 of 20 November. United Nations Human Rights. Retrieved February 22, 2018, from http://www.ohchr.org/en/professionalinterest/pages/crc.aspx

Denton, C.A. et al. (2003). Bringing research-based practice in reading intervention to scale. Learning Disabilities Research \& Practice, 18, 201-211. https://doi.org/10.1111/1540-5826.00075

Developmental Disabilities Assistance and Bill of Rights Act. (2000). P.L. 106-402.

Foreman, P. (2011). Inclusion in Action. Australia: Cengage Learning.

Foucault, M. (1977). Discipline and Punish. NY: Vintage Books.

Fujiura, G. (2003). Continuum of intellectual disability: Demographic evidence for the "forgotten generation. Mental Retardation, 41, 420-429. https://doi.org/10.1352/0047-6765(2003)41<420:COIDDE>2.0.CO;2

Gagné, F. (1983). From gifts to talents. Conceptions of giftedness. New York: Cambridge University Press.

Gardner, H. (1983). Frames of mind. New York: Basic Books.

Gersten, R. et al. (2001). Teaching reading comprehension strategies to students with learning disabilities: A review of the research. Review of Educational Research, 71, 279-320. https://doi.org/10.3102/00346543071002279

Goldin-Meadow, S. (2003). The resilience of language: What gesture creation in deaf children can tell us about how all children learn language. New York: Psychology Press.

Gross, M.U.M. (2008). Highly gifted students and adolescents. Critical issues and practices in gifted education: What research says. Waco, TX: Prufrock Press.

Groven, B. (2015). Inclusive education in Norway - core principles, ways and means in a school context. In Hrebeňárová, L. \& Kožárová, J. (Eds.), Dilemy inkluzívneho procesu v edukácii so zameraním na socializáciu osôb so špeciálnymi potrebami (pp. 31-42). Prešov: Vydavatel'stvo Prešovskej university.

Guidelines for Inclusion. (2005). Ensuring access to Education for All. UNESCO.

Hlebová, B., Ďord’ovičová, J., \& Pálková, V. (2015). Kognitívna stimulácia čitatel’skej kompetencie žiakov s l’ahkým stupňom mentálneho postihnutia v školskej integrácii. Prešov: vydavatel'stvo Prešovskej univerzity.

Hrebeňárová, L., Mandzáková, S. (2007). Súčasný stav individuálnej integrácie žiakov so špeciálnymi výchovno-vzdelávacími potrebami na prvom stupni základných škôl na Slovensku in Edukace žákỉ se speciálními vzdělávacími potřebami v. sborník přispěvků (pp.81-87). Ostrava: Pedagogická fakulta Ostravské univerzity v Ostravě.

Hrebeňárová, L. (2013). Vybrané aspekty edukácie žiakov s tažkým a hlbokým mentálnym postihnutím. Prešov: Vydavetel'stvo Prešovskej university.

Hrebeňárová, L., Žolnová, J., \& Palková, V. (2016). Perception of the frequency and importance of peer social support by students with special educational needs. International Journal of Social, Behavioral, Educational, Economic, Business and Industrial Engineering, 10(4), 1137-1141.

Inclusive education in Europe. (2016). German Commission for UNESCO. Retrieved February 11, 2018, from https://www.unesco.de/en/bildung/inklusive-bildung/inklusive-bildung-international/inklusive-bildung-euro pa.html

Kanner, L. (1943). Autistic disturbances of affective contact. Nervous Child, 2, 217-250.

Karchmer, M., \& Mitchell, R. (2003) Demographic and achievement characteristics of deaf and hard of hearing children. Deaf studies, Language, and Education, 29, 21-37.

Kauffman, J.M., Nelson, C.M., Simpson, R.L., \& Mock, D.R. (2011). Contemporary Issues. In Handbook of Special Education (pp. 15-26). New York: Routledge.

Landrum, T.J. (2011). Emotional and Behavioral Disorders. Handbook of Special Education (p. 209). New York: 
Routledge.

Lang, H. (2002). Higher education for deaf students: Research priorities in the new millennium. Journal of Deaf Studies and Deaf Education, 7, 267-280. https://doi.org/10.1093/deafed/7.4.267

Lechta, V. et al. (2010). Základy inkluzívnej pedagogiky. Praha: Portál.

Leigh, I. (2009). A lens of deaf identities. New York: Oxford University Press. https://doi.org/10.1093/acprof:oso/9780195320664.001.0001

Levelt, W.J.M. (1993). Speaking: From intention to articulation. Cambridge, MA: MIT Press.

Luckasson, R. (2002). Intellectual disability: Definition, classification, and systems of supports (10th ed.). Washington, D.C.: AAMR

Mandzáková, S., \& Pitoňáková, L. (2005) Pripravenost’ učitelov ZŠ na edukáciu žiakov so špeciálnymi výchovno-vzdelávacími potrebami $\mathrm{v}$ podmienkach individuálnej integrácie. In Príprava učitelov elementaristov a európsky mulitukultúrny priestor: zborník. Prešov: Pedagogická fakulta Prešovskej university.

Mastropieri, M.A., \& Scruggs, T.E. (2007). The Inclusive Classroom. Strategies for Effective Instruction. Upper Saddle River, NJ: Pearson, Merrill Prentice Hall.

Mrug, S. et al. (2009). Discriminating between children with ADHD and classmates using peer variables. Journal of Attention Disorders, 12, 372-580. https://doi.org/10.1177/1087054708314602

National Institutes of Mental Health (NIMH). (2009). Attention deficit hyperactivity disorder.

National Research Center on Learning Disabilities. (2007). SLD identification overview: General information and tools to get started.

Patton, J.R., \& Keyes, D. (2006). Death penalty issues following Atkins. Exceptionality, 14, 237-255. https://doi.org/10.1207/s15327035ex1404_5

Pastor, P.N., \& Reuben, C.A. (2008). Diagnosed attention deficit hyperactivity disorder and learning disability: United States, 2004-2006. Washington, D.C.: National Centre for Health Statistics, Series 10, Number 237.

Price, K.M., \& Nelson, K.L. (2007). Planning effective instruction. Belmont, CA: Thomson Higher Education.

Polloway, E.A. (2000). Influential persons in the development of the field of special education. Remedial and Special Education, 21, 322-324. https://doi.org/10.1177/074193250002100601

Polloway, E.A. (2006). Mild mental retardation: A concept in search of clarity, a population in search of appropriate education and supports, a profession in search of advocacy. Exceptionality, 14, 183-189. https://doi.org/10.1207/s15327035ex1404_1

Polloway, E.A. et al. (2010). Mild intellectual disabilities: Legacies and trends in concepts and educational practices. Education and Training in Developmental Disabilities, 45, 54-68.

Renzulli, J.S. (2005). The three-ring conception of giftedness: A developmental model for promoting creative productivity. Conceptions of giftedness. New York: Cambridge University Press. https://doi.org/10.1017/CBO9780511610455.015

Richards, T.L. (2007). Driving anger and driving behaviour in adults with ADHD. Journal of Attention Disorders, 10, 54-64. https://doi.org/10.1177/1087054705284244

Sandieson, R. (1998). A survey on terminology that refers to people with intellectual and developmental disabilities/developmental disabilities. Education and Training in Mental Retardation, 33, 290-295

Schalock, R.L. (2010) Intellectual disability: Definition, classification, and systems of supports. Washington, D.C.: AAIDD.

Schwartz, T.L. (2010). Causes of visual impairment: Pathology and its implications. Foundations of low vision: Clinical and functional perspectives. New York: AFB Press.

Semrud-Clikeman, M. (2009). Neuropsychological aspects for evaluating learning disabilities. Journal of Learning Disabilities, 38, 563-568. https://doi.org/10.1177/00222194050380061301

SNELL, M. E. et al. (2009). The characteristcis and needs of people with intellectual disabilities who have higher IQs. Intellectual and Developmental Disabilities, 47, 220-233. https://doi.org/10.1352/1934-9556-47.3.220 
Sullivan, K. (2014). Potential neural mechanisms underlying the effectiveness of early intervention for children with autism spectrum disorders. Research in Developmental Disabilities, 35, 2921-2932. https://doi.org/10.1016/j.ridd.2014.07.027

Swanson, H.L. (2009). Working memory, short-term memory, and reading disabilities: A selective meta-analysis of the literature. Journal of Learning Disabilities, 42, 175-196. https://doi.org/10.1177/0022219409331958

Tannenbaum, A.J. (1985). The enrichment matrix model. Systems and models for developing programs for the gifted and talented. Mansfield Center, CT: Creative Learning Press.

Tenbroek, J. (1966). The legal right to live in the world: the disabled in the law of torts. California Law Review, $54(1), 814$.

Tomasevski, K. (2004). Manual on right-based education. UNESCO Bangkok.

Tymchuk, A. J. et al. (2001). The forgotten generation. Baltimore: Brookes.

Universal Declaration of Human Rights (UDHR). (1948). Paris: United Nation. Retrieved February 22, 2018, from http://www.un.org/en/universal-declaration-human-rights/

U.S. Department of Education. (2009). Identifying and treating attention deficit hyperactivity disorder: A resource for home and school.

White, A, \& Duffy, S.H. (2014). Least Restrictive Environment. Encyclopedia of Special Education, 3, 1531-1533. Hoboken, NJ: John Wiley and Sons. https://doi.org/10.1002/9781118660584.ese1398

WHO. (2016). ICD-10 Classification of Mental and Behavioural Disorders: Clinical Descriptions and Diagnostic Guidelines. Geneva: WHO.

WHO. (2005). Mental health atlas. Geneva: World health organisation.

Wymbs, B.T. et al. (2008). Rate and predictors of divorce among parents of youth with ADHD. Journal of Consulting in Clinical Psychology, 76, 735-744. https://doi.org/10.1037/a0012719

Žolnová, J. (2014). Diet’a s problémovým správaním v materskej škole. Prešov: Vydavatel’stvo Prešovskej univerzity, Pedagogická fakulta.

\section{Copyrights}

Copyright for this article is retained by the author(s), with first publication rights granted to the journal.

This is an open-access article distributed under the terms and conditions of the Creative Commons Attribution license (http://creativecommons.org/licenses/by/4.0/). 